\title{
Soil depth and fertility effects on biomass and nutrient allo- cation in jaraguagrass
}

\author{
ALEJANDRO PIETERS AND ZDRAVKO BARUCH
}

Authors are former student, Escuela de Biologia, Facultad de Ciencias, Universidad Central de Venezuela, Caracas and professor, Departamento de Estudios Ambientales, Universidad Simon Bolivar, Apartado 89000 Caracas 1080. VENEZUELA.

\section{Abstract}

The African perennial $\mathrm{C}_{4}$ grass Hyparrhenia rufa (Nees) Stapf has successfully invaded the lowland non-flooded savannas of Venezuela except in isolated sites with a shallow lithoplinthic hardpan. To study the mechanism of this invasion process, an experiment was designed to determine the effect of soil fertility and depth of the lithoplinthic hardpan on growth, biomass, and nutrient allocation of $\boldsymbol{H}$. rufa. The main treatments were fertilization with nitrogen, phosphorus and potassium and mechanical disruption of the lithoplinthic horizon prior to seeding with $\boldsymbol{H}$. rufa at the beginning of the rainy season.

Soil fertility rather than soil depth is the predominant abiotic variable regulating the invasion and growth of $H$. rufa in savanna sites with a shallow lithoplinthic horizon. $H$. rufa exhibited flexibility in phenology, morphology, productivity and biomass allocation patterns in response to nutrient availability. These responses are typical of successful invader plants. Fertilization significantly increased plant growth through increased tillering and leaf production. Fertilization increased total and organ biomass by $1,000 \%$ and the highest proportion was allocated to reproductive tillers. In unfertilized plants, live leaves comprised the highest fraction $(-40 \%)$ of total biomass whereas the root/shoot ratio was about 0.3 in all treatments. $N$ concentration was $\sim 50 \%$ higher in roots and rhizomes than in other organs at the beginning of the dry season and under all treatments. Live leaves of unfertilized plants had higher $\mathbf{N}$ concentration than leaves of fertilized plants. Phosphorus and $K$ concentrations were similar among vegetative organs but $\sim 400 \%$ greater in reproductive tillers of fertilized plants. Fertilized plants had the greatest total content of mineral nutrients due to increased biomass production.

Key Words: biomass production, Hyparrhenia rufa; Neotropical savannas, plant invasion tropical soils

The lowland savannas of Venezuela have been used extensively for cattle grazing in spite of their low primary productivity, which is attributed to low soil fertility, seasonal drought and fire (Sarmiento 1984, Frost et al. 1986). Several African grasses, such as Hyparrhenia rufa (Nees) Stapf, have been introduced into Venezuela to improve forage quality. This species has spread

\footnotetext{
The authors wish to thank the Sociedad Venezolana de Ciencias Naturales for the work done at the Estación Biologica de los Llanos (Calabozo), for logistical help and living facilities. Drs. V. González, D. López, E. Medina, and A. Vivas provided usefu advice throughout the experimental work and commented the manuscript. Three anonymous referees improved the first version of this paper.

Manuscript accepted 28 May 1996.
}

aggressively and has displaced native plants from the most fertile habitats of the savanna (Parsons 1972, Baruch, and Fernández 1993).

Hyparrhenia rufa is a tufted, perennial, $\mathrm{C}_{4}$ grass which has higher productivity and marginally better nutritive quality than most native grasses. It is also considered to be fire and drought tolerant (Daubenmire 1972, Parsons 1972, Bogdan 1977). Its annual growth cycle starts with rains in May and peak biomass is attained by August-September. Flowering occurs during the short days of November-December and its aboveground live biomass decreases to a minimum during the dry season

The superior competitive ability of $H$. rufa, as compared to native species, has been attributed to its greater: (a) net photosynthetic rate (Baruch et al. 1985); (b) higher water and nutrient use efficiency (Bilbao and Medina 1990, Baruch and Fernández 1993, Baruch and Gómez 1996); (c) proportion of assimilates allocated to leaves (Baruch et al. 1989, Simoes and Baruch 1991); (d) tolerance to defoliation (Simoes and Baruch 1991) and (e) germination potential (Z. Baruch, unpublished results). The invasion of $H$. rufa has not occurred uniformly within the savanna. $H$. rufa is absent in sites with a surface lithoplinthic horizon although it may dominate deeper soils nearby. The former soils (called "arrecife" or "ripio" in Venezuela) are the least productive of the Venezuelan savannas due to very low fertility and restricted root penetration (García-Miragaya and Cáceres 1990). The objective of this study, which was part of a program to understand the success of African grasses in Neotropical savannas, was to investigate the effects of soil fertility and impedance to root penetration on the invasion and growth of $H$. rufa.

\section{Materials and Methods}

Field work was done at the Estación Biológica de los Llanos $\left(8^{\circ} 53^{\prime} \mathrm{N}\right.$ and $67^{\circ} 19^{\prime} \mathrm{W}, 80 \mathrm{~m}$ above sea level) $10 \mathrm{~km}$ south of Calabozo (Guárico State, Venezuela), on an area that had been protected from fire and grazing for the last 30 years. The climate is warm throughout the year (mean $=27.6^{\circ} \mathrm{C}$ ) and rainfall is strongly seasonal from May to November (annual mean $=1,300$ $\mathrm{mm}$ ). Soils of the study site originated from alluvial sediments ranging from clays to sands to cemented iron oxides. The latter constitute a reddish lithoplinthic hardpan at variable depths that is typical of the non-flooded savannas (López et al. 1971). In general, the soils are acidic, their nutrient and organic matter contents 
are low, and they are high in exchangeable aluminum (GarcíaMiragaya and Cáceres 1990, Medina 1982). At the study site, depth of the lithoplinthic hardpan determines the vegetation pattern: whcre it occurs at $-20 \mathrm{~cm}$ or deeper, the native graminoid genera Trachypogon, Axonopus, Andropogon, Aristida, and Bulbostylis are dominant (Ramia 1967). H. rufa invaded these relatively deep soils between 1969 and 1977 (San José and Fariñas 1991) and the native vegetation was displaced by a homogeneous cover of the alien grass (Baruch and Fernández 1993). However, where the lithoplinthic horizon is near the surface, a sparse native community ( $~ 35 \%$ cover) dominated by Trachypogon plumosus and Bulbostylis sp. persists and $H$, rufa is absent.

Five sites with a surface lithoplinthic horizon (R1-R5) were selected for the experiment. One additional site with lithoplinthic horizon at least $30 \mathrm{~cm}$ deep and $100 \%$ covered by $H$. rufa $(\mathrm{SH})$ was also sampled for comparison. Soil samples were taken from each site to analyze for bulk density, the soil fraction $>2 \mathrm{~mm}$ in diameter and soil texture (Cox 1976). The available clements were extracted with the North Carolina solution (Murphy and Riley 1963); P was determined by the molybdic-blue method (Murphy and Riley 1963), and the cations by flame spectrophotometry. Total soil $\mathrm{N}$ was extracted by digestion with concentrated $\mathrm{H}_{2} \mathrm{SO}_{4}$ and $30 \% \mathrm{H}_{2} \mathrm{O}_{2}$, and determined by titration with $0.01 \mathrm{~N}$ $\mathrm{HCl}$ (Jackson 1982). Organic matter was determined by the Walkley-Black method and $\mathrm{pH}$ was measured in water with a 2:5 soil:water ratio (Jackson 1982).

At each $\mathrm{R}$ site, four $2 \mathrm{~m} \times 2 \mathrm{~m}$ plots, separated by $50 \mathrm{~cm}$ wide buffers, were established and all plants were manually removed. One of the following treatments was applied to each plot: (i) surface fertilization with $70 \mathrm{~kg}$. ha ${ }^{-1}$ each of $\mathrm{N}$ as urea, $\mathrm{P}$ as triple superphosphate and $\mathrm{K}$ as $\mathrm{KCl}$ (treatment $\mathrm{F}$ ); (ii) mechanical rupture of the lithoplinthic horizon with a pickaxe to a depth of 20 $\mathrm{cm}$, and removal of pebbles $>5 \mathrm{~cm}$ in diameter which increased the effective soil depth (treatment D); (iii) fertilization + mechanical rupture (treatments $D+F$ ) and (iv) control, where only the plants were removed (treatment C). Assignment of the treatments to the plots of each site (block), was at random, resulting in a randomized complete block design. In addition, two $2 \mathrm{~m} \times 2 \mathrm{~m}$ plots were established in the SH site where only the dense cover of $H$. rufa was removed.

On 29 June $1991,250 \mathrm{~g}$ of commercial $H$. rufa seeds were surface applied to each plot. Germination occurred 1 week later and by 30 July, all except 7 seedlings (which was the lowest number of surviving seedlings) per plot were manually removed. Sampling started on 12 August. The first 3 samplings were 2 weeks apart, the next 4 were 3 weeks apart, and the last 2 sam- plings were 4 weeks apart. At each sampling, total number of leaves (live and dead) and culms or tillers on each plant were counted and invading plants were removed. On 9 January 1992, after the plants had reached their maximum seasonal growth, plots of sites R1, R2 and R3 and one of the SH plots were harvested. The remaining plots were harvested 4 weeks later due to logistic limitations. Each of the 7 plants in the plots was sampled. Belowground biomass was collected by excavating $15-\mathrm{cm}$ deep and $10-\mathrm{cm}$ in diameter around the base of the plant. This sampling probably recovered only part of the root systems. The plants were taken to the laboratory, separated into: (i) live leaves; (ii) dead leaves; (iii) culms; (iv) belowground organs (roots and rhizomes), and (v) reproductive organs (racemes). All parts were ovendried at $75^{\circ} \mathrm{C}$ and weighed. The organs of the plants from each plot were thoroughly mixed and ground through a 60-mesh sieve for $\mathrm{N}, \mathrm{P}$, and $\mathrm{K}$ determinations as described above. Soil samples were taken again for $\mathrm{N}, \mathrm{P}$, and $\mathrm{K}$ determination as described. Data were subjected to a two-way ANOVA and means were separated by the multiple rank Duncan test where appropriate (Sokal and Rohlf 1968). Statistical significance was assumed when $p<0.05$. Soil and plant results from the $2 \mathrm{SH}$ plots could not be statistically evaluated and are included and discussed for comparative purposes only.

\section{Results}

During the year of the experiment, rainfall was greater than the average for the previous 20 years $(1,440 \mathrm{~mm}$ vs. $1,300 \mathrm{~mm})$ and $89 \%$ of it fell between May and December. Pan evaporation was more than $100 \%$ greater than rainfall $(2,994 \mathrm{~mm})$ and annual mean air temperature was $27.9^{\circ} \mathrm{C}$ (Ministerio del Ambiente, Venezuela). Before fertilization, soil $\mathrm{P}, \mathrm{K}, \mathrm{Mg}$, organic matter and $\mathrm{pH}$ were similar in the experimental sites (R1-R5) and in the site dominated by $H$. rufa $(\mathrm{SH})$. However, $\mathrm{N}$ and $\mathrm{Ca}$ were higher in the SH site (Table 1). The soils were sandy and the $\mathrm{pH}$ was acidic in all sites, but the soil fraction $>2 \mathrm{~mm}$ in diameter and soil bulk density were greater in the $\mathrm{R}$ sites (Table 1). Soil analyses after harvest showed that fertilization had increased $P$ and $K$ significantly (by $466 \%$ and $139 \%$, respectively) but total $\mathrm{N}$ was not affected and remained around $2 \mathrm{mg} \mathrm{g}^{-1}$.

The number of live leaves increased exponentially in the first 3 samplings of the fertilized $\mathbf{R}$ plots, whereas in the unfertilized treatments the increase was much slower. The plants from the $\mathrm{SH}$ site showed an intermediate behavior (Fig. 1). Tiller numbers were significantly higher in fertilized plants (Table 2). The difference in growth among treatments caused a difference in pheno-

Table 1. Mean and SD (in parentheses) of the soil physical and chemical variables corresponding to the experimental sites (R) and the SH site (savanna dominated by $H$. rufa, average of 2 plots). Total soil nitrogen values are reported. B. D. $=$ bulk density; $F>2 \mathrm{~mm}$. $=$ fraction of soil $>$ than $2 \mathrm{~mm}$ in diameter.

\begin{tabular}{|c|c|c|c|c|c|c|c|c|c|c|c|c|}
\hline$\overline{\text { Site }}$ & $\mathbf{N}$ & $\mathbf{P}$ & $\mathbf{K}$ & $\mathrm{Ca}$ & $\mathbf{M g}$ & $\begin{array}{c}\text { Variable } \\
\text { O. M. }\end{array}$ & $\mathrm{pH}$ & Clay & Sand & Loam & B.D. & $\mathrm{F}>2 \mathrm{~mm}$ \\
\hline $\mathbf{R}$ & $\begin{array}{l}1700 \\
(600)\end{array}$ & $\begin{array}{c}4.1 \\
(0.3)\end{array}$ & $\begin{array}{c}32.2 \\
(4.9)\end{array}$ & $\begin{array}{l}16.1 \\
(5.3)\end{array}$ & $\begin{array}{l}18.2 \\
(2.4)\end{array}$ & $\begin{array}{c}1.4 \\
(0.1)\end{array}$ & $\begin{array}{c}5.1 \\
(0.1)\end{array}$ & $\begin{array}{c}12.0 \\
(1.5)\end{array}$ & $\begin{array}{l}59.7 \\
(1.9)\end{array}$ & $\begin{array}{l}19.8 \\
(1.8)\end{array}$ & $\begin{array}{c}0.8 \\
(0.1)\end{array}$ & $\begin{array}{c}0.7 \\
(0.1)\end{array}$ \\
\hline S. H. & 2600 & 3.6 & 28.2 & 32.8 & 18.4 & 1.3 & 5.1 & 15.2 & 55.2 & 21.3 & 0.5 & 0.4 \\
\hline
\end{tabular}


Table 2. Mean and SD ( in parentheses ) of total and organ biomass ( $\mathrm{g}$ plant ${ }^{1}$ ) corresponding to the treatments and S.H. (savanna dominated by $H$. rufa). Included are the two-way ANOVA significant differences $\left(^{*}\right)$ at $\mathbf{p}<0.05$. C=control; $F=$ fertilization effect; $D=$ depth effect; I=interaction (FxD). For each variable, values followed by the same letter are not statistically different at $\mathbf{p}<0.05$. Data for SH (Hyparrhenia rufa savanna) is the mean of 2 plots, was not subjected to statistical analysis, and is shown only for comparison.

\begin{tabular}{|c|c|c|c|c|c|c|c|}
\hline Variable & \multicolumn{4}{|c|}{ Treatment } & $F(2,12)$ & ANOVA & S.H. \\
\hline Dead Leaves & $\begin{array}{c}0.6 \mathrm{a} \\
(0.2)\end{array}$ & $\begin{array}{c}0.7 \mathrm{a} \\
(0.4)\end{array}$ & $\begin{array}{c}4.7 \mathrm{~b} \\
(1.4)\end{array}$ & $\begin{array}{c}3.4 \mathrm{~b} \\
(0.8)\end{array}$ & 13.8 & $\mathrm{~F}^{*}, \mathrm{I}, \mathrm{D}$ & 4.4 \\
\hline Culms & $\begin{array}{c}0.1 \mathrm{a} \\
(0.0)\end{array}$ & $\begin{array}{c}0.2 \mathrm{a} \\
(0.1)\end{array}$ & $\begin{array}{c}8.5 b \\
(3.4)\end{array}$ & $\begin{array}{c}5.5 \mathrm{~b} \\
(0.9)\end{array}$ & 13.1 & $F^{*}, \mathrm{I}, \mathrm{D}$ & 2.6 \\
\hline Reproductive Organs & $\begin{array}{r}0.1 \mathrm{a} \\
(0.2)\end{array}$ & $\begin{array}{r}0.1 \mathrm{a} \\
(0.3)\end{array}$ & $\begin{array}{c}2.5 \mathrm{~b} \\
(0.8)\end{array}$ & $\begin{array}{c}2.4 \mathrm{~b} \\
(0.6)\end{array}$ & 23.2 & $F^{*}, I, D$ & 0.6 \\
\hline Total Biomass & $\begin{array}{c}2.6 \mathrm{a} \\
(0.4)\end{array}$ & $\begin{array}{c}2.5 \mathrm{a} \\
(1.7)\end{array}$ & $\begin{array}{c}26.2 \mathrm{~b} \\
(7.0)\end{array}$ & $\begin{array}{c}20.6 \mathrm{~b} \\
(2.2)\end{array}$ & 27.1 & F*, I, D & 12.3 \\
\hline Root/Shoot Ratio & $\begin{array}{c}0.3 a \\
(0.06)\end{array}$ & $\begin{array}{c}0.3 \mathrm{a} \\
(0.10)\end{array}$ & $\begin{array}{c}0.3 \mathrm{a} \\
(0.08)\end{array}$ & $\begin{array}{c}0.3 \mathrm{a} \\
(0.06)\end{array}$ & 0.6 & $F, I, D$ & 0.3 \\
\hline
\end{tabular}

logical development: leaf and tiller numbers peaked 30-45 days earlier in the fertilized plants (Fig. 1). However, leaf death occurred simultaneously in all treatments and the SH site at the beginning of the dry season (January 1992).

Neither plant biomass nor nutrient concentration differed significantly between the 2 harvests, thus the data were pooled for statistical analysis. Fertilization was the only statistically signifi-

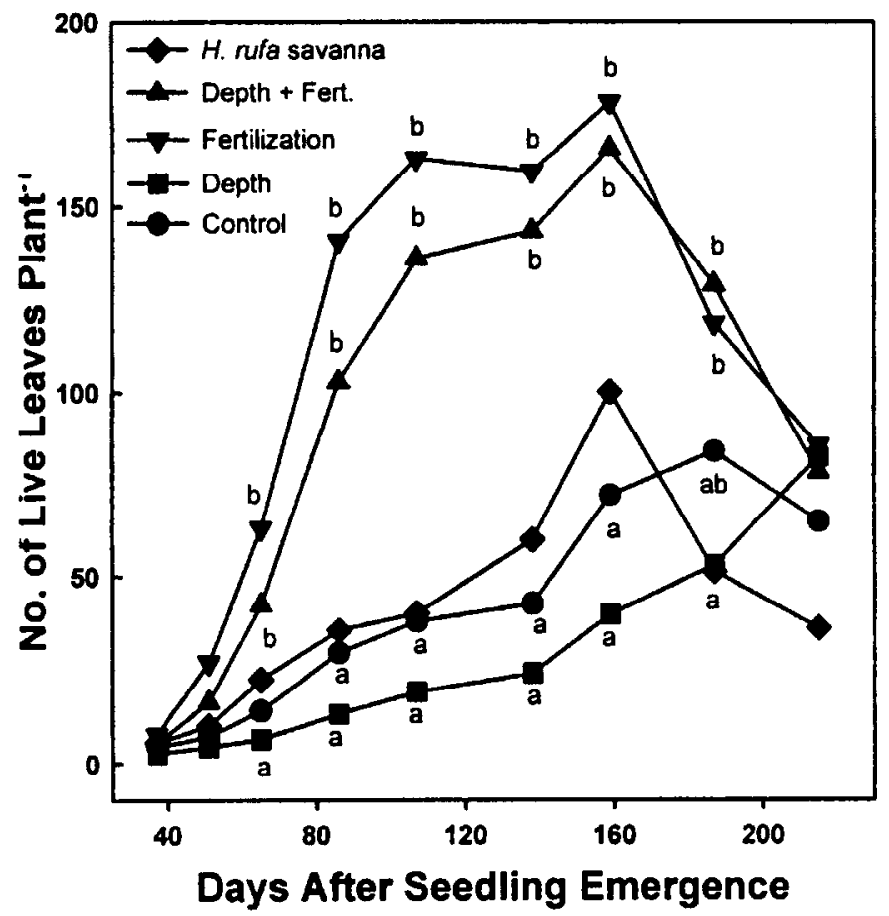

Fig. 1. Number of live leaves. plant-1 for each treatment and for the SH sites. For each sampling, treatments marked with the same letter are not statistically different at $P<0.05$. (Data from the $H$. rufa savanna are from 2 plots and are shown only for comparison). cant effect. Total plant and organ biomass were consistently and significantly higher in fertilization treatments (Table 2). The plants from the SH site generally had intermediate biomass which was closer to that of fertilized plants (Table 2). The highest proportion of total biomass was represented by live leaves in unfertilized plants and by roots and rhizomes in fertilized plants (Fig. 2). The fraction of culms and reproductive structures was signifi-

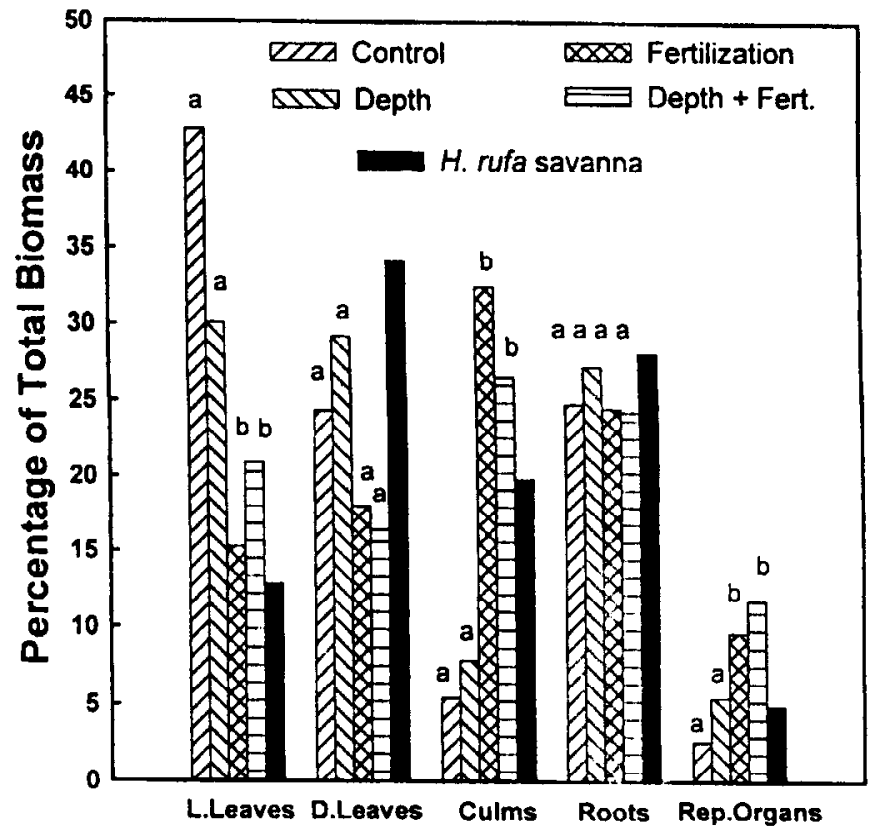

Fig. 2. Organ biomass as percent of total biomass under each treatment and the S.H. site (Data from the $H$. rufu savanna are from 2 plots and are shown only for comparison). For each organ, treatments marked with the same letter are not statistically different al $\mathbf{P}<0.05$. 


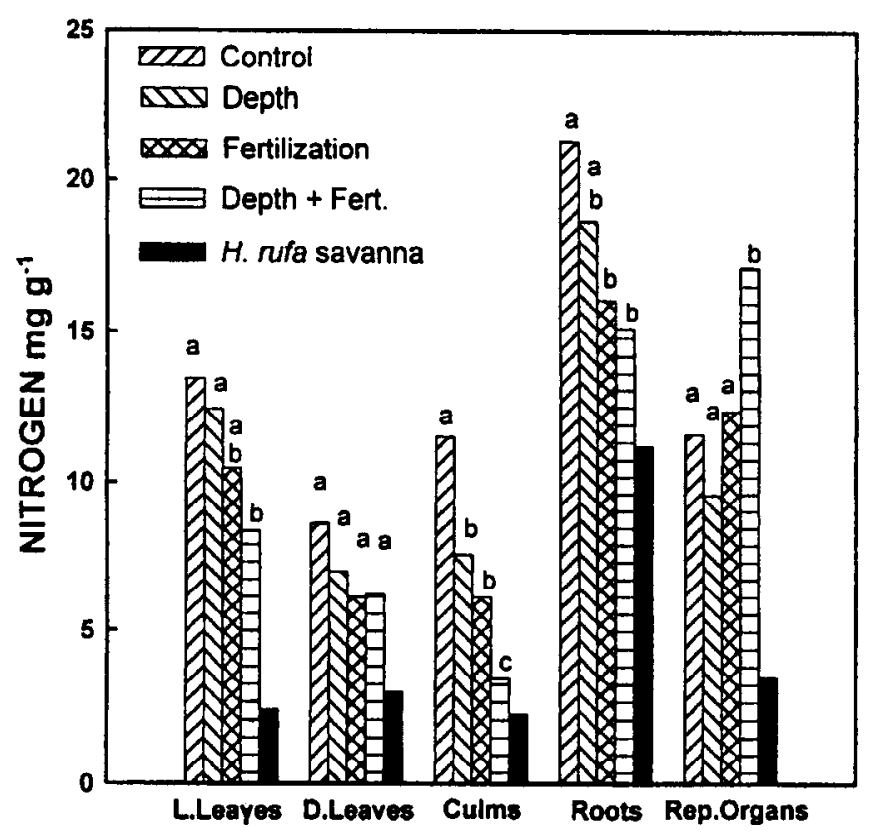

Fig. 3. Nitrogen concentration of the organs for each treatment and the S.H. site. Comments, symbols and statistics as in Fig. 2.

cantly higher in fertilized plants (Fig. 2). These allocation patterns resulted in a root/shoot ratio which was similar in all treatments (Table 2).

Among vegetative tissues, $\mathbf{N}$ concentration was significantly higher in underground organs in all treatments. Dead leaves had $~ 40 \%$ less $\mathbf{N}$ than live leaves except in plants from the SH site (Fig. 3). Vegetative organs of unfertilized plants had higher $\mathbf{N}$ concentrations than those of fertilized plants (Fig. 3). Total $\mathbf{N}$ content per plant organ was similar to biomass pattern, i. e. highest in the fertilization treatments, lowest in unfertilized plants and intermediate in SH plants. Phosphorus was more evenly distributed among vegetative organs than $\mathrm{N}$ in all treatments and $\mathrm{SH}$. However, reproductive organs of both fertilized treatments had $100 \%$ greater $P$ concentrations than vegetative organs (Fig. 4). In contrast to $\mathrm{N}$, the $\mathrm{P}$ present in live leaves remained there until they senesced. Total $\mathrm{P}$ content per plant had the same pattern as $\mathbf{N}$. Potassium concentration ranged from 5 to $10 \mathrm{mg} \mathrm{g}^{-1}$ in all organs and treatments except in reproductive organs of fertilized plants where the concentration was $\sim 500 \%$ higher (data not shown).

\section{Discussion}

The results show that growth and biomass production of $H$. rufa were more related to nutrient availability than to effective soil depth of the lithoplinthic soils typical of the well-drained savannas of Venezuela. Although only soil $\mathrm{N}$ and $\mathrm{Ca}$ concentrations were higher in the SH site, its lower bulk density and greater depth probably allowed the roots of $H$. rufa to exploit a larger volume of soil than in the $\mathrm{R}$ sites. Also, in the $\mathrm{R}$ sites, a high proportion of soil particles $(\sim 70 \%)$ was $>2 \mathrm{~mm}$ in diameter which was not analyzed for nutrient content. This fraction, com- posed of quartz pebbles and the lithoplinthic hardpan rich in iron oxides, has an extremely low nutrient concentration (GarcíaMiragaya and Cáceres 1990). Therefore, the difference in total nutrient availability between $\mathrm{R}$ and $\mathrm{SH}$ soils would be greater than our data on concentration suggest. This greater nutrient availability in the deeper SH soils apparently favors the invasion and growth of $H$. rufa. Added nutrients had contrasting behavior, $\mathrm{P}$ and $\mathrm{K}$ remained in the soil longer than $\mathrm{N}$ which probably was either leached or absorbed by plants.

Hyparrhenia rufa in fertilized plots grew larger and produced more leaves and culms than those in unfertilized plots due probably by increased carbon assimilation as found by Coughenour et al. (1985) in Hyparrhenia filipendula. Also, leaf and culm production was accelerated by fertilization. This faster vegetative growth probably aided sexual reproduction as fertilized plants flowered earlier and produced more reproductive biomass than unfertilized plants. This might have been largely due to $\mathbf{P}$ availability. High biomass accumulation, as found in fertilized $H$. rufa is typical of fast-growing species in fertile environments (Chapin 1980) and of invader plants (Bazzaz 1986). In contrast, native savanna grass production responds less to fertilization, whereas $\mathbf{N}$ and $\mathbf{P}$ concentrations in their live biomass increase (Medina et al. 1977, Bilbao and Medina 1990).

At harvest, the highest fraction of total biomass of unfertilized plants was live leaves, which suggests a delay in their annual growth cycle and reproduction or that soil $P$ levels were inadequate for reproduction. The root/shoot ratio was similar in all treatments indicating a high degree of rigidity in biomass allocation. This result should be interpreted with caution due to possible incomplete recovery of root biomass. Although nutrient availability regulated the growth of $H$. rufa, its effect was probably modulated by water availability. This was evidenced by leaf mortality which occurred synchronously in all treatments and in the

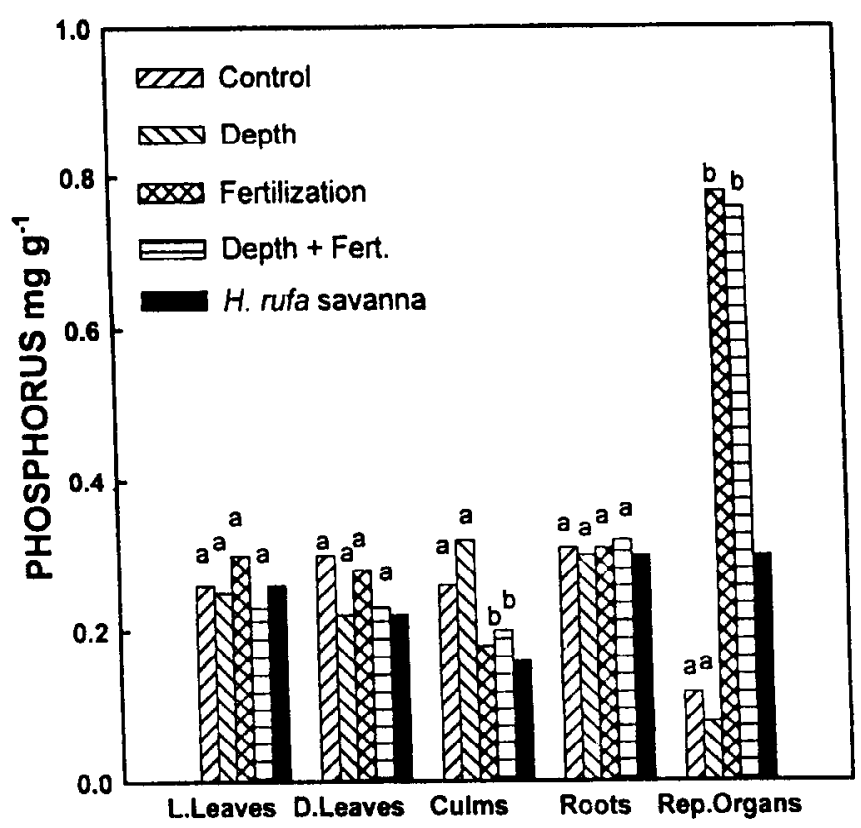

Fig. 4. Phosphorus concentration of the organs for each treatment and the S.H. site. Comments, symbols and statistics as in Fig. 2. 
SH site at the beginning of the dry season. Early leaf senescence is an important drought-evasion strategy in $H$. rufa (Baruch and Fernandez 1993).

Fertilization increased total nutrient content per organ due to increased biomass but nutrient concentration was more affected by internal allocation. Nitrogen concentration, was highest in the roots and rhizomes of all treatments and $\mathrm{SH}$, suggesting that they were the main $\mathbf{N}$ sink during the dry season and an important $\mathbf{N}$ source for the next growing season (Tergas and Blue 1971, Chapin 1988, Chapin et al. 1990). The low N concentration in dead leaves suggested that downward translocation of $\mathbf{N}$ from senescing leaves to roots and rhizomes took place. However, low $\mathrm{N}$ concentration in dead leaves of $\mathrm{SH}$ plants was not evident. The seasonal translocation has been reported in $H$. rufa and other tropical (Sarmiento 1992, Baruch and Gómez 1996) and temperate (Heckathorn and De Lucia 1994) grasses. The higher leaf $\mathrm{N}$ concentration in unfertilized as compared to fertilized plants could be caused by 3 mechanisms whose relative importance is difficult to distinguish: (i) Fertilization increased leaf biomass in $H$. rufa thus diluting $\mathrm{N}$ concentration (Medina et al. 1977, Chapin 1980); (ii) In unfertilized plants leaf $\mathrm{N}$ was not involved in growth due to P shortage (Bilbao and Medina 1990) and (iii) As discussed above, unfertilized plants were still vegetative and $\mathbf{N}$ translocation to roots and to reproductive organs was delayed. The low $\mathrm{N}$ concentration in SH plants as compared to unfertilized plants in $\mathbf{R}$ sites was probably caused by dilution of tissue $\mathbf{N}$ in the former due to its faster biomass production.

The uniform distribution of $P$ among vegetative organs of the plants in all treatments contrasts to that of $\mathrm{N}$ and indicates the lack of preferential accumulation and partitioning of this element as postulated by Medina (1993). This is interesting, particularly in unfertilized plants, since the existence of a strategy that permits the economy of $P$ should have been selected for in tropical savannas where $P$ is strongly limiting (Medina et al. 1977, Medina 1982, 1993). The contrasting behavior of $\mathrm{N}$ and $\mathrm{P}$ could be clarified considering that $H$. rufa evolved in African savannas (Clayton 1969; Bogdan 1977) on soils where P is less limiting than N (Anderson and Talbot 1965, Medina 1993). On the other hand, the high $P$ concentration in reproductive organs of fertilized plants is prominent and probably contributes, through increased reserves, to faster seedling growth after germination.

The results of this study indicate that $H$. rufa can establish on sites with shallow lithoplinthic hardpans if the competing vegetation is removed. Subsequently, soil fertility rather than effective depth regulated the permanence and growth of $H$. rufa on these sites. $H$. rufa showed flexibility in its phenological, architectural, productivity and biomass partitioning patterns in response to soil nutrient availability. Fertilization increased plant size and biomass whereas the absorbed nutrients were invested in growth and reproduction and reserves were accumulated in roots and rhizomes during the dry season. Low production of unfertilized plants induced $\mathrm{N}$ buildup in leaves and their vegetative growth period was longer which seemed to prevent the accumulation of sufficient reserves for sexual reproduction before the beginning of the dry season. This type of flexible response for nutrient use, plus the intrinsic high growth potential and the opportunistic use of water (Baruch et al. 1985, Baruch and Fernández 1993, Baruch 1996) partially explain the success of $H$. rufa in the non-flooded savannas of Venezuela.

\section{Literature Cited}

Anderson, G.D. and L.M. Talbot. 1965. Soil factors affecting the distribution of the grassland types and their utilization by wild animals on the Serengeti plains, Tanganyika. J. Ecol. 53:33-56.

Baruch, Z. 1996. Ecological aspects of the invasion by African grasses and their impact on biodiversity and function of Neotropical savannas. p. 79-93 In: O. Solbrig, E. Medina and J. Silva (eds). Biodiversity and Savanna Ecosystem Processes. Ecological Studies 121. SpringerVerlag, Berlin, Germany.

Baruch, Z. and D.S. Fernandez. 1993. Water relations of native and introduced $\mathrm{C}_{4}$ grasses in a Neotropical Savanna. Oecologia 96: 179-185.

Baruch, Z. and Gomez, J.A. 1996. Dynamics of energy and nutrient concentration and construction costs in a native and two alien $\mathrm{C}_{4}$ grasses from two Neotropical savannas. Plant \& Soil (in press).

Baruch, Z., A.B. Hernandez, and G.M. Montilla. 1989. Dinámica del crecimiento, fenología y repartición de biomasa en gramíneas nativas e introducidas de una sabana Neotropical. Ecotropicos 2: 1-13.

Baruch, Z., M.M. Ludlow, and R. Davis. 1985. Photosynthetic responses of native and introduced $C_{4}$ grasses from Venezuelan savannas. Oecologia 67:388-393.

Bazzaz, F.A. 1986. Life history of colonizing plants: some demographic, genetic and physiological features. p. 96-110 In: H.A. Mooney and J. A. Drake (eds). Ecology of Biological Invasions of North America and Hawaii. Ecological Studies 58. Springer-Verlag, N.Y.

Bilbao, B. and E. Medina. 1990. Nitrogen use efficiency for growth in a cultivated African grass and a native South American pasture grass. J. Biogeogr. 17:421-425.

Bogdan, A.V. 1977. Tropical pastures and fodder plants. Tropical Agricultural Series. Longman, London.

Chapin, F.S. 1980. The mineral nutrition of wild plants. Ann. Rev. Ecol. Syst.11:233-260.

Chapin, F.S. 1988. Ecological aspects of plant mineral nutrition. Adv. Mineral Nutrition 3:161-190.

Chapin, F.S., F.D. Schulze, and H.A. Mooney. 1990. The ecology and economics of storage in plants. Ann. Rev. Ecol. Syst. 21:423-447.

Clayton, W.D. 1969. A revision of the genus Hyparrhenia. Kew Bulletin. Additional Series II. Her Majesty's Stationary Office, London.

Coughenour, M.B., S.J. McNaughton, and L.L. Wallace. 1985. Responses of an African tall-grass (Hyparrhenia filipendula Stapf.) to defoliation and limitations of water and nitrogen. Oecologia 68:80-86.

Cox, E. 1976. Laboratory manual of general ecology. (2nd ed.). W.C. Brown. Co., N.Y.

Daubenmire, R. 1972. The ecology of Hyparrhenia rufa (Nees) in derived savanna in North-western Costa Rica. J. Appl. Ecol. 9:11-23.

Frost, P., E. Medina, J.C. Menaut, O.T. Solbrig, B. Swift, and B.J. Walker. 1986. Responses of savannas to stress and disturbance. Internat. Union of Biol. Sci. Special Issue 10.

Garcia-Miragaya, J. and A. Caceres. 1990. Soil chemistry changes in a forest-grassland vegetation gradient within a fire and grazing protected savanna from the Orinoco Llanos, Venezuela. Acta Oecol. 11:775-781.

Heckathorn, S.A. and E.H. De Lucia. 1994. Drought-induced nitrogen retranslocation in perennial $\mathrm{C}_{4}$ grasses of tallgrass prairie. Ecol. 75:1877-1886.

Jackson, M. 1982. Análisis químico de suelos. Prentice Hall, Englewood Cliffs, N.Y.

Lopez, D., P. Roa, and I. Ramirez. 1971. Estudios en un sedimento ferruginoso llamado localmente "ripio". Boletín de la Sociedad Venezolana de Ciencias Naturales 129:27-49.

Medina, E. 1982. Physiological ecology of Neotropical savanna plants. p. 303-335 In: D.J. Huntley and B.H. Walker (cds.). Ecology of tropical savannas. Ecological Studies 42. Springer-Verlag, Berlin, Germany.

Medina, E. 1993. Mineral nutrition: tropical savannas. Progr. Bot. $54: 237-253$ 
Medina, E., A. Mendoza, and R. Montes. 1977. Balance nutricional y producción de materia orgánica en las sabanas de Calabozo, Venezuela. Boletín de la Sociedad Venezolana de Ciencias Naturales 134:100-120.

Murphy, J. and J.P. Riley. 1963. A modified single method for the determination of phosphate in natural waters. Anal. Chem. Acta 27:31-35.

Parsons, J.J. 1972. Spread of African pasture grasses to the American tropics. J. Range Manage. 25:12-17.

Ramia, M. 1967. Algunos tipos de sabanas de los Llanos de Venezuela. Boletín de la Sociedad de Ciencias Naturales 112:264-288.

San Jose, J.J. and M. Farinas. 1991. Temporal changes in the structure of a Trachypogon savanna protected for 25 years. Acta Oecol. $12: 237-247$
Sarmiento, G. 1984. The Ecology of Neotropical savannas. Harvard Univ. Press. Cambridge, Mass.

Sarmiento, G. 1992. Adaptive strategies of perennial grasses in South American savannas. J. Veg. Sci. 3: 325-336.

Simoes, M. and Z. Baruch. 1991. Responses to simulated herbivory and water stress in two tropical $C_{4}$ grasess. Oecologia 88:173-180.

Sokal, R. and F.J. Rohlf. 1968. Biometry. W.H. Freeman and Company, San Francisco, Calif.

Tergas, L.E. and W.G. Blue. 1971. Nitrogen and phosphorus in jaraguagrass (Hyparrhenia rufa (Nees) Stapf) during the dry season in a tropical savanna as affected by nitrogen fertilization. Agron. J. 63:6-9. 